\title{
Executive Functions: Relation between Evaluation by Parents and Teachers and the Performance of Children
}

\author{
Alana Tosta Martoni \\ Early Childhood and Elementary Education of the City Hall São Paulo, \\ São Paulo, SP, Brazil \\ Bruna Tonietti Trevisan \\ Developmental Disorders Post-Graduation Program, Universidade \\ Presbiteriana Mackenzie, São Paulo, SP, Brazil \\ Natalia Martins Dias ${ }^{1}$ \\ Educational Psychology Post-Graduation Program, Centro Universitário FIEO, \\ Osasco, SP, Brazil \\ Alessandra Gotuzo Seabra \\ Developmental Disorders Post-Graduation Program, Universidade \\ Presbiteriana Mackenzie, São Paulo, SP, Brazil
}

\begin{abstract}
Executive functions (EF) enable individuals to regulate their behavior. In children, these abilities have been evaluated by performance tests and scales completed by parents/teachers. However, the literature has shown that the correlation between different types of psychological measures and between different respondents is, at best, moderate. This study investigated: (a) the concordance between parents and teachers in rating scales of EF and indicators of inattention and hyperactivity, and (b) the relation between scores in the scales and the performance of children in a test of inhibition, a component of EF. Participants were 144 children (mean age $=6.16 \mathrm{y}$ ) of the $1^{\text {st }}$ and $2^{\text {nd }}$ phases of Early Childhood Education and $1^{\text {st }}$ grade of Elementary Education of a public school in a city of São Paulo, their parents and teachers. Parents and teachers completed the Childhood Executive Functioning Inventory (CHEXI) and MTA-SNAP-IV. Children responded to the Semantic Stroop Test. There were significant correlations, low to moderate, between responses of parents and teachers in the scales. Correlations were more frequent in $1^{\text {st }}$ phase children. Parents indicated more difficulties than teachers in the children. Low to moderate correlations between the performance of the children in the Stroop test and responses of informants were found. With school progression, the CHEXI tended to correlate with increasingly complex measures of the Stroop test. Therefore, there was concordance, generally low, between the scales and performance test, as well as between the responses of parents and teachers, corroborating the importance of considering different sources of information in childhood evaluation.
\end{abstract}

Keywords: Cognitive process, child development, child assessment, executive functions, attention.

\footnotetext{
Mailing address: UniFIEO - Centro Universitário Fundação Instituto de Ensino para Osasco, Programa de Pós Graduação Stricto Sensu - Psicologia Educacional, Avenida Franz Voegeli, 300, Bloco Prata, Bairro Continental, Osasco, SP, Brazil 06020-190. Phone: (11) 3651-9914. E-mail: alana.martoni@gmail.com, brunattrevisan@gmail.com, natalia.dias@unifieo.br and alessandragseabra@gmail.com Financial support: Fundação de Amparo à Pesquisa do Estado de São Paulo (FAPESP) and National Counsel of Technological and Scientific Development (CNPq) Productivity Scholarship.
} 


\section{Funções Executivas: Relação entre Relatos de Pais, de Professores e Desempenho de Crianças}

\section{Resumo}

Funções executivas (FE) possibilitam ao indivíduo regular seu comportamento. Em crianças, têm sido avaliadas por meio de testes de desempenho e escalas preenchidas por pais/professores. Porém, a literatura tem demonstrado que a concordância entre diferentes tipos de medidas psicológicas e entre diferentes respondentes é, no máximo, moderada. Este estudo investigou: (a) a concordância entre pais e professores em escalas de avaliação de FE e de indicadores de desatenção e hiperatividade, e (b) as relações entre as pontuações nas escalas e o desempenho de crianças em um teste de inibição, um componente das FE. Participaram 144 crianças (idade média=6,16a) de $1^{\mathrm{a}}$ e $2^{\mathrm{a}}$ fase do Ensino Infantil e $1^{\circ}$ ano do Fundamental de uma escola pública de uma cidade da Grande São Paulo, seus pais e professores. Pais e professores responderam ao Inventário de Funcionamento Executivo Infantil (IFEI) e ao MTA-SNAP-IV. As crianças responderam ao Teste de Stroop Semântico. Houve correlações significativas, baixas a moderadas, entre respostas de pais e de professores nas escalas, sendo essas correlações mais frequentes nas crianças da $1^{a}$ fase. Pais indicaram mais dificuldades nas crianças do que os professores. Foram encontradas correlações, de baixas a moderadas, entre desempenho das crianças no Stroop e respostas dos informantes. Com a progressão escolar, o IFEI tendeu a se correlacionar com medidas mais complexas do Stroop. Portanto, houve concordância, em geral baixa, entre escalas e teste de desempenho, assim como entre respostas de pais e de professores, corroborando a importância de considerar diferentes fontes de informação na avaliação infantil.

Palavras-chave: Processos cognitivos, desenvolvimento infantil, avaliação infantil, funções executivas, atenção.

\section{Funciones Ejecutivas: Relación entre Evaluación por Padres, Maestros y Rendimiento de los Niños}

\section{Resumen}

Funciones ejecutivas (FE) permiten regular lo comportamiento. En niños, han sido evaluados por pruebas de rendimiento y escalas respondidas por padres/maestros. La literatura ha demostrado que la correlación entre diferentes tipos de medidas e entre diferentes informantes es, el mejor, moderado. Este estudio investigó: (a) el acuerdo entre padres y maestros en escalas de evaluación de FE e de indicadores de desatención e hiperactividad, y (b) la relación entre puntuaciones en escalas y rendimiento de los niños en una prueba de inhibición, un componente de FE. Participaron 144 niños (edad media=6,16a) de las $1^{\mathrm{a}}$ e $2^{\mathrm{a}}$ fases de la Educación Infantil y de lo $1^{\mathrm{o}}$ año de la Primaria de una escuela pública de São Paulo, sus padres y maestros. Padres y maestros completaron el Inventario de funcionamiento ejecutivo Infantil (IFEI) y MTA-SNAP-IV. Los niños respondieron a la prueba de Stroop Semántico. Hubo correlaciones significativas, bajas a moderadas, entre las respuestas de padres y maestros en las escalas, siendo estas más comunes en la $1^{\text {a }}$ fase. Los padres indicaron más dificultades en los niños que los maestros. Fueron encontradas correlaciones, bajas a moderadas, entre el rendimiento de los niños en el Stroop y las respuestas de los informantes. Con la progresión escolar, el IFEI tendió a correlacionarse con medidas más complejas de Stroop. Por tanto, hubo concordancia, en general baja, entre escalas y pruebas de rendimiento, así como entre las respuestas de padres y maestros, lo que corrobora la importancia de considerar diferentes fuentes de información in la evaluación infantil.

Palabras-clave: Procesos cognitivos, desarrollo infantil, evaluación infantil, funciones ejecutivas, atención. 
Executive functions are skills that enable individuals to control and regulate the processing of information and their behavior (Diamond, 2013; Gazzaniga, Ivry, \& Mangun, 2006). These skills are always required when, due to the novelty or complexity of the task or situation, automatic processing is not appropriate or is insufficient to solve it (Menezes, Godoy, Teixeira, Carreiro, $\&$ Seabra, 2012). These skills have been widely discussed in the literature, especially with regard to the multidimensionality of the construct (Fonseca et al., 2010). There is relative consensus that executive functions consist of three main skills, inhibition, working memory and cognitive flexibility (Diamond, 2013; Miyake, Friedman, Emerson, Witzki, \& Howerter, 2000). Other skills frequently mentioned in the literature as associated with executive functions, such as planning and decision-making (Gazzaniga et al., 2006; Lezak, Howieson, \& Loring, 2004; Malloy-Diniz, Sedo, Fuentes, \& Leite, 2008), are considered more complex skills that result from the integration of the three main skills.

Inhibition has two main functions. One is related to response inhibition, for example, to inhibit behavior in an environment where it is not appropriate, allowing individuals to control their actions and respond appropriately to environmental requirements (i.e., to exercise selfcontrol). The other function is related to cognitive inhibition, which refers to the inhibition of thoughts and distractors (Diamond, 2013; Nigg, 2001), being intrinsically related to selective attention, in turn understood as a mechanism that enables the processing of relevant information, while ignoring other irrelevant or distracting information (Gazzaniga et al., 2006). Working memory refers to the ability to mentally sustain information to use in a given task, integrating it with other information or while performing another activity. It allows information to be manipulated (i.e., the individual may operate with and transform the information; Baddeley, 2000; Diamond, 2013; Gazzaniga et al., 2006). Cognitive flexibility can be considered more complex than the first two as it depends, to some extent, on the previous skills. Flexibility allows the individual to simultaneously cope with diverse information and tasks. It is related to the ability to change perspective and is fundamental for the ability to adapt behavior to changing situations and social demands (Diamond, 2013).

The development of these skills begins to occur around the first year of life. It is considered that the first ability to emerge, at around 12 months, is inhibitory control, with working memory and flexibility starting to develop after this age. Despite this early start, the development of executive functions continues throughout childhood, until mid-adolescence and early adult life. In the preschool age group, the focus of this study, there is an important development of these skills. Between four and five years of age, children become increasingly adept at focusing attention, controlling behavior and have greater control of their emotions, being more able to follow rules and adapt their behavior to social demands. Between five and six years of age, they are able to plan and solve simple problems (Dawson \& Guare, 2010; García-Molina, Enseñat-Cantallops, Tirapu-Ustárroz, \& RoigRovira, 2009). A review of the development of executive functions can be consulted in Dias and Seabra (2013).

In the school environment, these skills are required and can be promoted, since the situations presented require the child to formulate solutions for proposed problems, plan and adapt to various situations in the pursuit of new targets, these characteristics being intrinsically related to executive functions. Therefore, on one hand, while the school environment, by requiring these skills, may have the potential to foment them, on the other, children who enter school with poor executive functions are more likely to have difficulties in controlling their behavior, learning and organizing for work and activities. Such problems tend to increase with the growing complexity of the tasks over the course of the school years, which imposes increasing demands to their already poor executive skills (Dawson \& Guare, 2010).

Academic performance, measured in terms of marks, is positively related to executive functions (Capovilla \& Dias, 2008). There is also evidence that children who start school with 
poorer functions are likely to become increasingly resistant to schooling, to strive less and abandon activities more rapidly (Blair \& Razza, 2007; Vitaro, Brendgen, Larose, \& Tremblay, 2005). Additionally, according to Blair and Diamond (2008), the difficulty of children to fulfill the school demands can produce in teacher attitudes of anger and frustration, helping to foster feelings of failure in the child and withdrawal of the student from the environment in question. In contrast, children with higher levels of executive functions tend to like to receive instruction and to focus more on the tasks, considering the school to be easy and the activities enjoyable (Vitaro et al., 2005).

Changes in executive functions have also been shown to be related to cognitive and neuropsychiatric disorders, such as Attention Deficit Hyperactivity Disorder - ADHD (Gonçalves et al., 2013; Willcutt, Doyle, Nigg, Faraone, \& Pennington, 2005), in which, according to Barkley (1997), inhibitory control is especially reduced. Furthermore, significant relations, although low, between skills of the executive functions and indicators of inattention and hyperactivity were found in a non-clinical sample consisting of healthy preschool children in a previously conducted study (Pereira, León, Dias, \& Seabra, 2012). The signs of ADHD already mentioned, namely, inattention and hyperactivity, can lead to different impairments, for example, inappropriate interactions with parents, leading to conflicts also in the family environment (Guilherme, Mattos, Serra-Pinheiro, \& Regalla, 2007). Specifically in relation to academic performance, individuals with ADHD tend to present greater difficulty in completing education, with more chances of repetition and low performance compared to their peers (Malloy-Diniz et al., 2008). Together, this evidence shows the importance of studying the development of executive functions and their relation with signs of inattention and hyperactivity with individuals in the school environment.

Thus, both the executive deficit in itself, as well as the signs of inattention and hyperactivity that may be present in children can influence their school and family functioning. Therefore, it is essential that the executive skills and signs of inattention and hyperactivity could be evaluated early in children of preschool age, as identifying changes may allow the introduction of interventions in early phases (Pereira et al., 2012).

There are different forms of evaluation, such as performance testing and functional measures, as questionnaires and scales, which tend to be widely used for screening for certain deficits or disorders. There is a tendency to expect consistent results when applying the various measures (for example, performance test x scale) to evaluate the same construct or related constructs, or when using the same screening instrument with different informants (such as parent $\mathrm{x}$ teacher), when the intention is, for example, to obtain information about the behavior of the child. However, the results do not always show a homogeneity (Major \& Seabra-Santos, 2013; Pereira et al., 2012; Seabra-Santos \& Gaspar, 2012).

A relatively recent study that investigated this question in preschool children is that of Seabra-Santos and Gaspar (2012). The authors evaluated different aspects of childhood development from a scale completed by parents and teachers. The degree of agreement between parents and teachers ranged from low to moderate and the parents presented a tendency to evaluate the children with better performance compared to teachers. The authors also found a correlation between reports from parents and teachers and the performances of the children in an IQ test. The classifications of the parents and teachers were only weakly, at the most moderately, related to the performance of children in the IQ test and large discrepancies in the correlations established between the performance test and reports of parents or teachers were not noted. The authors concluded that the different environments (home x school) allowed different possibilities for observing the behavior. Also in a sample of preschool children, another study showed that the evaluation of indicators of inattention and hyperactivity by the teacher presented the highest number of correlations, although low, with measures in performance tests when compared to the same evaluation performed by the parents (Pereira et al., 2012). 
Differences between responses by different informants have received increased attention in the literature and been the focus of discussion by researchers. Such discrepancies between reports may be due, at least in part, to expectations in relation to the children and their behavior in different environments (Homer et al., 2000). Evaluation using scales is, to some degree, subjective and the differences observed in several studies may reflect different judgments and interpretations of the items of the instrument, as well as being influenced by many other factors, including the relationship that the adult has with the child or adolescent evaluated (Zucker, Morris, Ingram, Morris, \& Bakeman, 2002). According to Major and Seabra-Santos (2013), behavioral rating scales have assumed an important role, especially in the evaluation of children in the preschool age group, enabling the collection of information about different aspects of behavior in different situations and contexts. The degree of concordance between different informants, however, is only modest and several factors may be related to this, including the tendency of an informant to be very benevolent/critical, lack of comprehension of the items of the instrument or ignorance of the behavior (normal-pathological spectrum) evaluated, as well as errors inherent to the items themselves, which may for example refer to situations with different meanings for different informants, being interpreted differently by each of them. In addition, according to the authors, the evaluation context, i.e., the environmental situation (stimuli, reinforcers) in which behavior may or may not occur, and the subjectivity of the informant can be intricate factors in the way parents and teachers complete childhood behavior rating scales.

Specifically with regard to ADHD, studies have also found differences between reports of parents and teachers. When investigating the concordance of parents and teachers in relation to the symptoms of children and adolescents with the disorder, Mitsis, McKay, Schulz, Newcorn and Halperin (2000) found a low relation between responses, especially regarding the disorder subtypes. The same has been observed in national studies. In a clinical sample of children and adolescents, aged six to 16 years, using the MTA-SNAP-IV, researchers found that teachers were more conservative in reporting symptoms than parents. The parents presented more complaints about the behavior of their children, reporting high rates of symptoms compared with the teachers (Coutinho, Mattos, Schmitz, Fortes, $\&$ Borges, 2009). With the same screening instrument, however, in a non-clinical sample of children and adolescents, aged between 10 and 16 years, another study provided evidence that parents and teachers have different score profiles for the MTA-SNAP-IV subscales and are probably influenced by cultural aspects (SerraPinheiro, Mattos, \& Regalla, 2008).

Considering the need for early evaluation of executive functions and possible signs of inattention and hyperactivity in children, as well as the divergence, exposed in the literature, between reports of different informants, the present study evaluated preschool and early elementary school children in a test of executive function, specific for selective attention and inhibitory control, and in scales of executive functioning and signs of inattention and hyperactivity, completed by parents and teachers. The aims of this study were: (a) to verify the relation between the scales completed by parents and teachers, and (b) to investigate the relation between the scores in the scales and the performance of the children in the performance test. The study hypothesis was that there would be concordance, however low, between the responses of the parents and teachers in the scales used. Similarly, the concordance between the different measures (scale x performance test) should be low, possibly moderate, between the specific measures (e.g. subscale of inhibitory control of the executive functions rating scale and performance test, which evaluates inhibition).

\section{Method}

\section{Participants}

Participants were children in the preschool and school phase, aged between 4 and 7 years, and their parents and teachers. The sample was 
by convenience, with all the students of Early Childhood Education classes and the $1^{\text {st }}$ grade of Elementary Education whose parents gave authorization to participate in the study. Participants were 144 students, of both genders, from a single Municipal School of Early Childhood Education and Elementary Education, located in a neighborhood with medium and mediumlow socioeconomic level of a city of greater São Paulo. The sample consisted of 38 students of the $1^{\text {st }}$ phase of Early Childhood Education (mean age $=5.1$ years, $S D=.29$ ), 33 of the $2^{\text {nd }}$ phase of Early Childhood Education (mean age $=6.3$ years, $S D=.29)$ and 73 children of the $1^{\text {st }}$ grade of Elementary Education I (mean age = 6.43 years, $S D=.35$ ).

\section{Instruments}

$M T A-S N A P-I V . \quad$ The MTA-SNAP-IV (Swanson, Nolan, \& Pelham - IV Questionnaire, or SNAP-IV, version used in the 'Multimodal Treatment Study for ADHD' - MTA) includes 26 items related to symptoms of criterion A of the DSM-IV for ADHD (subscales of inattention and hyperactivity/impulsivity, each with nine items) and to symptoms of Oppositional Defiant Disorder. This study used only the subscales of inattention (e.g. "Often does not seem to listen when spoken to directly") and hyperactivity/impulsivity ("Often leaves seat in the classroom or in other situations in which remaining seated is expected"). The instrument was adapted and validated in Brazil by Mattos, Serra-Pinheiro, Rohde and Pinto (2006). It is completed by parents and teachers, who score, on a Likert scale of four levels, how much each statement is characteristic of the behavior of the child. Higher scores in each subscale indicate increased presence of indicators of the disorder.

Childhood Executive Functioning Inventory (CHEXI). The Brazilian version (Trevisan et al., 2011; Trevisan, Dias, Berberian, \& Seabra, in press) was translated and adapted from the questionnaire of Thorell and Nyberg (2008). The CHEXI is composed of 26 items divided into four subscales: working memory (e.g., "Has difficulty understanding verbal instructions unless he/she is also shown how to do something"), planning ("Has difficulty with tasks or activities that involve several steps"), inhibitory control ("Has a tendency to do things without first thinking about what could happen") and regulation ("Has clear difficulty doing things he/she finds boring"). It is completed by parents and teachers, who score, on a Likert scale of five points, how much each statement is characteristic of the behavior of the child. Higher scores indicate greater difficulty.

Semantic Stroop Test (SST). This test evaluates the inhibitory component of FE, including selective attention and inhibitory control. In this version, developed based on Berwid, Kera, Santra, Bender and Halperin (2005), the words, original stimuli of the Stroop test, are replaced by pairs of pictures corresponding to "day" and "night", "boy" and "girl", and "large" and "small". In the first part of the test the child must name the pictures and in the second say the opposite noun (e.g.: say "boy" when presented with the picture of the "girl"). Each part of the test has 16 items totaling 32 pictures, which are presented in a time of 300 milliseconds. In the application of the test the scores and reaction times were recorded for the first and second parts of the test. In addition, the correct response and the interference reaction time were calculated. That is, the mean of the correct responses in part 2 (incongruent) subtracting the mean of the correct responses in part 1 (congruent), and the mean reaction time from part 2 (incongruent) subtracting the mean reaction time in part 1 (congruent). Evidence of validity of the SST in Brazilian children is published in Trevisan (2010).

\section{Procedure}

After approval from the Ethics Committee, contact was made with the Department of Education of the city and, through this, with the directors of the participating school. After the consent from the director of the school, the parents were contacted at the time of the parents and teachers meeting, when they were explained the aims and procedures of the study and delive- 
red the Consent form. After approximately one week, with the return of the signed forms, the data collection was started. The children were evaluated individually with the SST in a single session lasting approximately 10 minutes. The evaluation took place at the school during the regular school term, in the second half of the school year, and was conducted by three researchers (one Doctoral candidate; two Master's students). The parents and teachers were given the CHEXI and MTA-SNAP-IV and were asked to complete the questionnaires and return them to the researchers by the end of the data collection period. They were given clear instructions, in writing, to complete and return the scales. The responses to the instruments were made autonomously, without the presence or assistance of the researchers. Nevertheless, the researchers remained in the school throughout the collection period and were available to answer questions from the parents and teachers and to assist in completing the scales when needed. There was a return of $93.05 \%$ of the scales given to the parents and $100 \%$ of the scales given to the teachers.

\section{Results}

As the performances of the participants were not distributed in compliance with the normal curve, not-parametric analyses were conducted.
Spearman's correlation analysis was used to investigate the relation between the scores in the CHEXI and in the MTA-SNAP-IV completed by parents and teachers and Wilcoxon analysis to compare the responses from parents and teachers to the instruments. Next, Spearman's correlation was used to verify the relation between responses to the scales and performance in the SST. Analyses were conducted for the sample as a whole and for each school level separately, to allow a more detailed comprehension of the relation between the measures in the different grades evaluated.

Table 1 shows the relation between the scores in the scales (CHEXI and MTA-SNAP-IV) completed by the parents and teachers. There were a greater number of correlations between the responses of parents and teachers in the MTA-SNAP-IV measures than in CHEXI measures. However, even considering only the MTA-SNAP-IV, it was observed that the relations found were low to moderate (only one correlation considered high was identified in the 'hyperactivity' indicator in the $1^{\text {st }}$ phase, with $r$ $=.67 ; p<.001)$. In the CHEXI, only the score on the 'Inhibitory Control' scale presented a relation between reports of parents and teachers, in the $1^{\text {st }}$ phase and total sample. The results also highlighted a downward trend in the number of relations with school progression.

Table 1

Matrix of Spearman's Correlations between the Scores in the CHEXI and in the MTA-SNAP-IV Completed by Parents and Teachers

\begin{tabular}{|c|c|c|c|c|c|c|c|}
\hline & \multicolumn{7}{|c|}{ Correlations between scores of parents and teachers } \\
\hline & \multicolumn{5}{|c|}{ CHEXI } & \multicolumn{2}{|c|}{ MTA-SNAP-IV } \\
\hline & $\mathrm{IC}$ & WM & PL & RG & Tot & Ina & Нyp \\
\hline General & $.25^{*}$ & .09 & .10 & .18 & .19 & $.36^{* *}$ & $.39^{* *}$ \\
\hline $1^{\text {st }}$ Phase & $.43 *$ & .15 & .29 & .24 & .22 & $.44^{*}$ & $.67 * *$ \\
\hline $2^{\text {nd }}$ Phase & .26 & .20 & .13 & .04 & .28 & $.39 *$ & .27 \\
\hline $1^{\text {st }}$ Grade & .08 & .03 & -.04 & .22 & .10 & .29 & .12 \\
\hline
\end{tabular}

Note. IC: inhibitory control; WM: working memory; PL: planning; RG: regulation; Tot: total; Ina: Inattention; Hyp: Hyperactivity. $* p<.05 ; * * p<.01$. 
Table 2 presents the descriptive statistics and the Wilcoxon $Z$ test. Some significant differences between the scores given by parents and teachers were identified in both the CHEXI and MTA-SNAP-IV scales. In all cases, considering both the overall sample and the specific school levels, the parents attributed higher scores, that is, evaluated children as having greater difficulties in comparison to the evaluation of teachers.

Spearman's correlation analysis was also conducted between the performance of children in the SST and the scores in the scales completed, considering both parents and teachers. Tables 3, 4 and 5 show these results for each school level.

As shown in Table 3, according to the response of the parents, there were significant relations between the score in inhibitory control of the CHEXI and the reaction time in the congruent part of the SST and between the total score in the CHEXI and the score in part 1 of the SST. Considering the teachers, there was a significant relation between the indicators of working memory and planning of the CHEXI and the score in part 1 of the SST.

Table 4 illustrates the results of the children of the $2^{\text {nd }}$ phase. According to the responses of the parents, there were significant relations between the working memory, inhibitory control, planning subscales and total of the CHEXI and the reaction time in part 2 of the SST. The planning and total subscales in the CHEXI were related to the reaction time in part 1 of the SST. Considering the perspective of the teachers, significant correlations were observed between the scores in planning and working memory of the

Table 2

Descriptive Statistics and Wilcoxon $Z$ in the CHEXI and MTA-SNAP-IV Completed by Parents and Teachers for the Total Sample and for Each School Level

\begin{tabular}{|c|c|c|c|c|c|c|c|c|c|c|c|c|c|c|}
\hline & \multicolumn{10}{|c|}{$\begin{array}{l}\text { CHEXI } \\
M(S D)\end{array}$} & \multicolumn{4}{|c|}{$\begin{array}{l}\text { MTA-SNAP-IV } \\
M(S D)\end{array}$} \\
\hline & \multicolumn{2}{|c|}{ IC } & \multicolumn{2}{|c|}{ WM } & \multicolumn{2}{|c|}{ PL } & \multicolumn{2}{|c|}{$\mathrm{RG}$} & \multicolumn{2}{|c|}{ Tot } & \multicolumn{2}{|c|}{ Ina } & \multicolumn{2}{|c|}{ Нyp } \\
\hline & 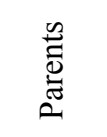 & 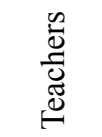 & 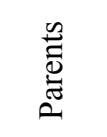 & 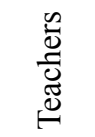 & 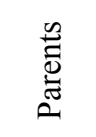 & 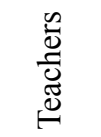 & 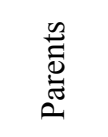 & 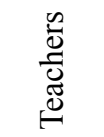 & 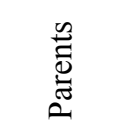 & 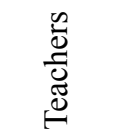 & 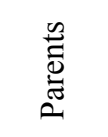 & 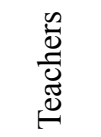 & 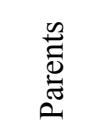 & $\begin{array}{l}\frac{\infty}{0} \\
\frac{\vec{U}}{0} \\
\stackrel{\mathbb{E}}{\oplus}\end{array}$ \\
\hline General & $\begin{array}{l}16.55 \\
(4.82)\end{array}$ & $\begin{array}{c}13.9 \\
(5.25)\end{array}$ & $\begin{array}{l}20.12 \\
(6.82)\end{array}$ & $\begin{array}{l}19.87 \\
(8.16)\end{array}$ & $\begin{array}{c}8.92 \\
(3.36)\end{array}$ & $\begin{array}{c}8.89 \\
(3.56)\end{array}$ & $\begin{array}{l}13.95 \\
(4.16)\end{array}$ & $\begin{array}{l}11.76 \\
(4.56)\end{array}$ & $\begin{array}{c}62.04 \\
(17.25)\end{array}$ & $\begin{array}{c}56.89 \\
(21.43)\end{array}$ & $\begin{array}{c}8.11 \\
(6.97)\end{array}$ & $\begin{array}{c}5.67 \\
(6.15)\end{array}$ & $\begin{array}{c}8.32 \\
(5.99)\end{array}$ & $\begin{array}{c}4.56 \\
(6.13)\end{array}$ \\
\hline$Z$ & \multicolumn{2}{|c|}{-3.573} & \multicolumn{2}{|c|}{-.549} & \multicolumn{2}{|c|}{-.373} & \multicolumn{2}{|c|}{-3.629} & \multicolumn{2}{|c|}{-1.514} & \multicolumn{2}{|c|}{-2.985} & \multicolumn{2}{|c|}{-5.705} \\
\hline$p$ & \multicolumn{2}{|c|}{$<.001$} & \multicolumn{2}{|c|}{.583} & \multicolumn{2}{|c|}{.709} & \multicolumn{2}{|c|}{$<.001$} & \multicolumn{2}{|c|}{.130} & \multicolumn{2}{|c|}{.003} & \multicolumn{2}{|c|}{$<.001$} \\
\hline $\begin{array}{c}1^{\text {st }} \\
\text { Phase }\end{array}$ & $\begin{array}{l}17.31 \\
(5.51)\end{array}$ & $\begin{array}{l}15.32 \\
(5.79)\end{array}$ & $\begin{array}{l}20.14 \\
(8.06)\end{array}$ & $\begin{array}{l}23.21 \\
(9.65)\end{array}$ & $\begin{array}{c}8.86 \\
(3.56)\end{array}$ & $\begin{array}{l}10.24 \\
(3.92)\end{array}$ & $\begin{array}{l}14.11 \\
(4.61)\end{array}$ & $\begin{array}{l}13.08 \\
(4.89)\end{array}$ & $\begin{array}{c}64.69 \\
(20.03)\end{array}$ & $\begin{array}{c}66.79 \\
(24.83)\end{array}$ & $\begin{array}{c}5.5 \\
(4.75)\end{array}$ & $\begin{array}{c}7.68 \\
(7.48)\end{array}$ & $\begin{array}{c}9.44 \\
(6.57)\end{array}$ & $\begin{array}{c}7.13 \\
(7.69)\end{array}$ \\
\hline$Z$ & \multicolumn{2}{|c|}{-2.646} & \multicolumn{2}{|c|}{-.883} & \multicolumn{2}{|c|}{-1.094} & \multicolumn{2}{|c|}{-1.842} & \multicolumn{2}{|c|}{-.265} & \multicolumn{2}{|c|}{-.565} & \multicolumn{2}{|c|}{-2.406} \\
\hline$p$ & \multicolumn{2}{|c|}{.008} & \multicolumn{2}{|c|}{.377} & \multicolumn{2}{|c|}{.274} & \multicolumn{2}{|c|}{.065} & & 91 & $.5^{\circ}$ & 72 & .0 & 16 \\
\hline $\begin{array}{c}2^{\text {nd }} \\
\text { Phase }\end{array}$ & $\begin{array}{l}15.47 \\
(3.75)\end{array}$ & $\begin{array}{l}13.94 \\
(4.97)\end{array}$ & $\begin{array}{l}19.64 \\
(6.34)\end{array}$ & $\begin{array}{c}18.70 \\
(6.9)\end{array}$ & $\begin{array}{c}9.0 \\
(3.48)\end{array}$ & $\begin{array}{c}8.3 \\
(3.09)\end{array}$ & $\begin{array}{l}13.83 \\
(3.54)\end{array}$ & $\begin{array}{l}11.55 \\
(4.39)\end{array}$ & $\begin{array}{c}62.28 \\
(15.55)\end{array}$ & $\begin{array}{c}56.45 \\
(18.72)\end{array}$ & $\begin{array}{c}5.56 \\
(4.36)\end{array}$ & $\begin{array}{c}4.97 \\
(6.35)\end{array}$ & $\begin{array}{c}7.28 \\
(4.94)\end{array}$ & $\begin{array}{c}4.12 \\
(6.44)\end{array}$ \\
\hline$Z$ & -1.7 & 794 & -.1 & 78 & & 070 & -2.3 & 360 & -1 & 442 & -1.5 & 911 & -3.3 & 19 \\
\hline$p$ & .07 & 73 & .85 & 59 & & 85 & .01 & 18 & & 49 & .0 & 56 & .0 & 01 \\
\hline $\begin{array}{c}1^{\text {st }} \\
\text { Grade }\end{array}$ & $\begin{array}{l}16.73 \\
(4.9)\end{array}$ & $\begin{array}{c}13.16 \\
(5.0)\end{array}$ & $\begin{array}{c}20.38 \\
(6.4)\end{array}$ & $\begin{array}{l}18.68 \\
(7.45)\end{array}$ & $\begin{array}{c}8.9 \\
(3.22)\end{array}$ & $\begin{array}{c}8.46 \\
(3.43)\end{array}$ & $\begin{array}{l}13.92 \\
(4.28)\end{array}$ & $\begin{array}{l}11.18 \\
(4.38)\end{array}$ & $\begin{array}{c}60.35 \\
(16.53)\end{array}$ & $\begin{array}{c}51.93 \\
(19.04)\end{array}$ & $\begin{array}{l}11.76 \\
(8.17)\end{array}$ & $\begin{array}{l}4.95 \\
(5.1)\end{array}$ & $\begin{array}{c}8.27 \\
(6.18)\end{array}$ & $\begin{array}{l}3.43 \\
(4.6)\end{array}$ \\
\hline$Z$ & -1.8 & 351 & -.2 & 34 & & 71 & -2.2 & 210 & -1 . & 076 & -3.6 & 658 & -3.5 & 47 \\
\hline$p$ & .06 & 64 & .81 & 15 & & 86 & .02 & 27 & & 82 & $<.0$ & 001 & $<$. & 01 \\
\hline
\end{tabular}

Note. IC: inhibitory control; WM: working memory; PL: planning; RG: regulation; Tot: total; Ina: Inattention; Hyp: Hyperactivity. 
Table 3

Matrix of Spearman's Correlations between Performance in the Stroop Test and Performances in the CHEXI and MTA-SNAP-IV, Completed by Parents and Teachers for the $\mathbf{1}^{\text {st }} \mathbf{P h a s e}$

\begin{tabular}{|c|c|c|c|c|c|c|c|c|}
\hline & & & \multicolumn{6}{|c|}{ Semantic Stroop Test } \\
\hline & & & \multicolumn{2}{|c|}{ Part 1} & \multicolumn{2}{|c|}{ Part 2} & \multicolumn{2}{|c|}{$\begin{array}{c}\text { Interference } \\
\text { (part } 2 \text { - part 1) }\end{array}$} \\
\hline & & & Score & RT & Score & RT & Score & RT \\
\hline \multirow[t]{7}{*}{ Parents } & CHEXI & IC & -.34 & $-.38^{*}$ & -.003 & -.002 & .094 & .27 \\
\hline & & WM & -.31 & -.14 & -.02 & .02 & -.001 & .06 \\
\hline & & PL & -.29 & -.13 & .05 & -.08 & .09 & -.02 \\
\hline & & $\mathrm{RG}$ & -.26 & -.29 & .10 & -.18 & .12 & .02 \\
\hline & & Tot & $-.36^{*}$ & -.29 & .004 & -.09 & .04 & .09 \\
\hline & SNAP & Ina & -.31 & -.07 & .06 & -.15 & .08 & -.04 \\
\hline & & Нyp & -.30 & -.32 & -.07 & -.07 & .08 & .21 \\
\hline \multirow[t]{7}{*}{ Teachers } & CHEXI & IC & -.27 & .07 & -.17 & -.22 & .06 & -.16 \\
\hline & & WM & $-.38^{*}$ & .18 & -.25 & -.16 & -.01 & -.16 \\
\hline & & PL & $-.40^{*}$ & .01 & -.27 & -.26 & .06 & -.17 \\
\hline & & $\mathrm{RG}$ & -.22 & -.05 & -.21 & -.19 & -.04 & -.07 \\
\hline & & Tot & -.34 & .13 & -.25 & -.25 & .01 & -.22 \\
\hline & SNAP & Ina & -.25 & -.09 & -.19 & .07 & -.03 & .11 \\
\hline & & Нyp & -.18 & -.15 & .04 & -.03 & .24 & .14 \\
\hline
\end{tabular}

Note. RT: reaction time. IC: inhibitory control; WM: working memory; PL: planning; RG: regulation; Tot: total; Ina: Inattention; Hyp: Hyperactivity.

$* p<.05$.

CHEXI and performance in part 1 of the SST. A relation was also observed between the indicator of inattention of the MTA-SNAP and the scores in part one and interference scores of the SST.

As shown in Table 5, in the $1^{\text {st }}$ grade, no relation was observed with the MTA-SNAP-IV indicators. Considering the CHEXI completed by parents, there were correlations between the inhibitory control subscale and interference reaction time in the SST, and between regulation and reaction time in part 2 of the SST. For the teachers, inhibitory control was the only measure of the CHEXI that presented a correlation with the score of part 2 of the performance test. It should be noted that the evaluation made by parents in the inhibitory control subscale of the CHEXI was the only index that was related with some measure of the SST in all the school levels.

\section{Discussion}

The first aim of the study was to verify the concordance between parents and teachers regarding the evaluation of executive functions and signs of inattention and hyperactivity. Relatively few relations were found between the measures evaluated by the parents and by the teachers, and the relations found tended to present low to moderate magnitude. This low level of agreement between the parents and teachers is consistent with the literature (Coutinho et al., 2009; Homer et al., 2000; Major \& Seabra-Santos, 2013; Mitsis et al., 2000; Seabra-Santos \& Gaspar, 2012; Serra-Pinheiro et al., 2008; Zucker et al., 2002). Interestingly, these authors evaluated different constructs, however, their results converge in relation to 
Table 4

Matrix of Spearman's Correlations between Performance in the Stroop Test and Performances in the CHEXI and MTA-SNAP-IV, Completed by Parents and Teachers for the $2^{\text {nd }}$ Phase

\begin{tabular}{|c|c|c|c|c|c|c|c|c|}
\hline & & & \multicolumn{6}{|c|}{ Semantic Stroop Test } \\
\hline & & & \multicolumn{2}{|c|}{ Part 1} & \multicolumn{2}{|c|}{ Part 2} & \multicolumn{2}{|c|}{$\begin{array}{c}\text { Interference } \\
(\text { part } 2 \text { - part } 1)\end{array}$} \\
\hline & & & Score & RT & Score & RT & Score & RT \\
\hline \multirow[t]{7}{*}{ Parents } & CHEXI & IC & .03 & -.27 & -.11 & $-.50 * *$ & -.14 & -.29 \\
\hline & & WM & -.11 & -.31 & -.03 & $-.36^{*}$ & -.05 & -.06 \\
\hline & & PL & -.18 & $-.51 * *$ & .04 & $-.52 * *$ & .09 & -.10 \\
\hline & & $\mathrm{RG}$ & .16 & -.27 & .12 & -.21 & -.02 & -.01 \\
\hline & & Tot & -.08 & $-.39 *$ & -.01 & $-.45^{*}$ & -.04 & -.10 \\
\hline & SNAP & Ina & -.18 & -.28 & -.17 & -.26 & -.09 & .02 \\
\hline & & Нyp & .19 & -.12 & .02 & -.01 & -.16 & .14 \\
\hline \multirow[t]{7}{*}{ Teachers } & CHEXI & $\mathrm{IC}$ & -.10 & -.23 & -.07 & -.14 & .12 & -.05 \\
\hline & & WM & $-.40^{*}$ & .03 & -.36 & .09 & -.01 & .11 \\
\hline & & PL & $-.43 *$ & -.02 & -.29 & .05 & .07 & .11 \\
\hline & & $\mathrm{RG}$ & -.29 & -.03 & -.37 & -.09 & -.03 & -.02 \\
\hline & & Tot & -.34 & -.10 & -.31 & -.08 & .04 & .03 \\
\hline & SNAP & Ina & $-.50 * *$ & -.16 & -.12 & -.30 & $.39 *$ & -.09 \\
\hline & & Нyp & -.06 & $-.43 *$ & -.04 & $-.39 *$ & .11 & -.11 \\
\hline
\end{tabular}

Note. RT: reaction time. IC: inhibitory control; WM: working memory; PL: planning; RG: regulation; Tot: total; Ina: Inattention; Hyp: Hyperactivity.

$* p<.05 ; * * p<.01$.

the same overall standard of low, or at the most moderate, concordance between parent and teacher informants.

Authors have tried to explain this trend of low concordance between informants regarding child and youth behavior as a function of the expectations that each evaluator has in relation to the subject, of the differing judgments and interpretations of the items of the scales used and of the environment in which the observation occurs (Homer et al., 2000; Major \& SeabraSantos, 2013; Zucker et al., 2002). As suggested by Seabra-Santos and Gaspar (2012), the differences between the environment at home and school might induce the occurrence of different behaviors which could then be observable by one informant, but not by the other. It is a fact that parents and teachers deal with the child in quite different contexts in terms of stimuli, structure and rules, among others. In this sense, the low degree of concordance should not necessarily be seen as negative, but as complementary. That is, different environments and informants may allow different possibilities for information about the child (Major \& Seabra-Santos, 2013).

Another point of interest refers to the variation with respect to the degree of concordance in different subscales. For example, parents and teachers had greater agreement regarding the evaluation of inhibitory control of the children by the CHEXI. However, no relation was found in the other subscales of the CHEXI, working memory, regulation, planning, or even in the total score. Regarding the MTASNAP-IV, despite variability of the coefficients, there were low correlations in all the subscales 
Table 5

Matrix of Spearman's Correlations between Performance in the Stroop Test and Performances in the CHEXI and MTA-SNAP-IV, Completed by Parents and Teachers for the $1^{\text {st }}$ Grade

\begin{tabular}{|c|c|c|c|c|c|c|c|c|}
\hline & & & \multicolumn{6}{|c|}{ Semantic Stroop Test } \\
\hline & & & \multicolumn{2}{|c|}{ Part 1} & \multicolumn{2}{|c|}{ Part 2} & \multicolumn{2}{|c|}{$\begin{array}{c}\text { Interference } \\
\text { (part 1-part 2) }\end{array}$} \\
\hline & & & Score & $\mathrm{RT}$ & Score & RT & Score & RT \\
\hline \multirow[t]{7}{*}{ Parents } & CHEXI & IC & .10 & .11 & -.24 & -.34 & -.28 & $-.42 *$ \\
\hline & & WM & .13 & -.05 & -.11 & .05 & -.31 & .003 \\
\hline & & PL & .15 & .001 & -.01 & -.27 & -.22 & -.25 \\
\hline & & RG & .11 & -.13 & -.10 & $-.37^{*}$ & -.22 & -.23 \\
\hline & & Tot & .12 & -.02 & -.12 & -.27 & -.29 & -.31 \\
\hline & SNAP & Ina & -.22 & .33 & -.003 & .27 & .15 & -.03 \\
\hline & & Нyp & -.18 & .26 & -.12 & .06 & -.01 & -.21 \\
\hline \multirow[t]{7}{*}{ Teachers } & CHEXI & IC & .06 & -.11 & $.28 *$ & -.15 & .19 & -.04 \\
\hline & & $\mathrm{WM}$ & .04 & -.05 & .24 & -.16 & .12 & -.14 \\
\hline & & PL & .01 & -.06 & .19 & -.11 & .09 & -.05 \\
\hline & & RG & .04 & -.04 & .16 & -.19 & .07 & -.13 \\
\hline & & Tot & .03 & -.04 & .24 & -.16 & .13 & -.11 \\
\hline & SNAP & Ina & -.09 & .01 & .20 & -.13 & .19 & -.12 \\
\hline & & Нyp & -.01 & .05 & .12 & -.03 & .05 & -.04 \\
\hline
\end{tabular}

Note. RT: reaction time. IC: inhibitory control; WM: working memory; PL: planning; RG: regulation; Tot: total; Ina: Inattention; Hyp: Hyperactivity.

$* p<.05 ; * * p<.01$.

for the overall sample and the correlations were moderate to high when considering the children of the $1^{\text {st }}$ phase. This variation in the level of concordance in different measures may be due to the nature of the evaluated construct and/or difficulty in observing and measuring it. For example, considering the age group of the children participating in this study (from 4 to 7 years), it may be easier for parents and teachers to observe and score items related to inhibitory control, such as 'Acts in a wilder way compared to other children in a group', than items that involve more complex behaviors or those more difficult to evaluate, such as those of other scales, for example the planning scale, 'Has difficulty planning for an activity'. This variation in the degree of concordance as a function of the construct was also evident in the data of Seabra-
Santos and Gaspar (2012). The authors found different relations between parents and teachers in the relationship, communication and learning dimensions, however, no relation in the selfregulation dimension. It should also be noted that the comprehension of the items of the scales depends on the characteristics of the respondents (Major \& Seabra-Santos, 2013). Therefore, it is possible that the parents of the sample, from a public school, had an interpretation different to that made by the teachers, which may help understand the differences in the reports made.

In addition to the variability of the degree of concordance in the different dimensions evaluated, the study also showed that the agreement of parents and teachers differed as a function of the school level. A greater number of relations between scores of parent and teacher 
was identified when considering the younger children, of the $1^{\text {st }}$ phase (inhibitory control of the CHEXI; inattention and hyperactivity of the MTA-SNAP-IV), with a decrease of relations found in the $2^{\text {nd }}$ phase (inattention of the MTASNAP-IV) and no significant relation observed in the $1^{\text {st }}$ grade. A possible hypothesis for this occurring could be that the demands of school and home are becoming increasingly distinct, that is, what is expected of the child in the school environment becomes quite different from what is expected of him/her at home, especially from entry into the more structured environment of Elementary Education.

Complementing this information, it was shown that the parents attributed more signs of inattention and hyperactivity to their children, as well as greater difficulties in inhibitory control and regulation. Although the sample of this study was non-clinical, the results were similar to those obtained by Coutinho et al. (2009) in children and adolescents with ADHD, which led the authors to conclude that parents present more complaints about the behavior of the children. A possible source of divergence between informants, in this case between parents and teachers, refers to the tendency of an informant be very benevolent or critical. Other sources of divergence relate to the different contexts (home and school) that supported the evaluation of parents and teachers and to the knowledge that each informant has about the behavior (if it would be adequate for a given age group) under evaluation (Major \& Seabra-Santos, 2013). In this sense, a possible hypothesis to comprehend this result would be that parents have a tendency to overestimate behavioral difficulties of the children and the teacher, due to better understanding of childhood development and the presence of references for comparison (other children), would be in a better position for the evaluation of the child.

The second aim of the study was to investigate the relation between the scores in the scales (CHEXI and MTA-SNAP-IV) and the performance of the children in an inhibition test, the Semantic Stroop Test. A previous study also conducted with preschool children showed some correlations, although low, between performance in executive function tests and indicators of inattention and hyperactivity (Pereira et al., 2012). However, unlike these findings, in the present study few relations were identified and, among those identified, there were some inconsistencies. For example, relations between performance in measures of the Semantic Stroop Test and scores in the MTA-SNAP-IV by teachers were only identified in the $2^{\text {nd }}$ phase. The correlations indicated that the most inattentive children tended to commit more errors in part 1 of the test. This could be explained, among other hypotheses, by the initial novelty of the task, for example, perhaps these children take a little longer to be able to engage in the activity. However, this worse performance in part 1 , when applied to the formula 'performance in part 2 - performance in part 1' for extracting the interference score, led to an overestimated effect (more positive, indicating less conflict). This result was also related to the scale of inattention by the teachers and, therefore, the children evaluated as more inattentive tended to present less interference effect. The relations between hyperactivity and reaction time in parts 1 and 2 of the SST present theoretical consistency, suggesting that children with signs of hyperactivity tend to be faster in both parts of the instrument, possibly responding more impulsively, consistent with some findings of Pereira et al. (2012).

Another aspect refers to the relation between the measures of the performance test and of the CHEXI. Few correlations were found between the measures and all with low to moderate magnitude. Another investigation also found only moderate correlation between a cognitive dimension evaluated through responses of parents and teachers and performance in an IQ test (Seabra-Santos \& Gaspar, 2012), suggesting that the scales, rather than substituting performance tests, could be a tool that allowed a rough approximation of the performance of the child.

A brief interpretation of the results shows that, in the $1^{\text {st }}$ phase, children evaluated by the parents as having greater difficulty in inhibitory control tended to be faster in part 1 of the SST, perhaps due to responding more impulsively. Furthermore, those evaluated with greater 
difficulties in overall executive functioning also made more mistakes in part 1 of the test. In the evaluation of the teachers, children with lower scores in working memory or planning tended to also make more mistakes in part 1 of the SST, which was also observed in the $2^{\text {nd }}$ phase. In this level, children evaluated by parents with greater difficulties in working memory and inhibitory control tended to respond more quickly to the second part of the SST, while those evaluated with more difficulty in planning and overall executive functioning presented this pattern of faster responses in both parts 1 and 2 of the test. A possible explanation for these results is that these children tend to contemplate less before emitting a response, which would explain their faster reaction time. In the $1^{\text {st }}$ grade, children evaluated by parents as having greater difficulty in inhibitory control tended to present longer times for the solution of the conflict imposed by the SST, suffering greater interference effect; those with greater difficulty in regulating tended to require more time in part 2 , incongruent, of the test. Conversely, in the evaluation of the teachers, children considered to have more difficult in inhibitory control tended to present higher scores in part 2 of the SST, this being an unexpected and theoretically inconsistent result. It is possible that this result reflects a less accurate evaluation of the ability for inhibitory control by the teachers, however, this hypothesis needs further support, since this finding occurred only in this school level.

An interesting aspect to be noted, however, is that over the course of successive school levels, the correlations of the CHEXI subscales began to occur with the more complex measures of the performance test. Thus, in the $1^{\text {st }}$ phase, the executive abilities evaluated by parents and teachers related with the score and reaction time in part 1 of SST, which only requires the naming of the pictures. In the $2^{\text {nd }}$ phase, although the correlation was still established with the score and time of part 1 , others, especially considering the evaluation of the parents, were established with the reaction time of part 2. Finally, in the $1^{\text {st }}$ grade, the relations found were between measures of the CHEXI and score and time in part 2 and interference of the performance test, suggesting that children with better regulation skills, according to the responses of the parents, and inhibition, according to the parents and teachers, performed better in the Stroop Test. This may have occurred due to a more adequate evaluation by the parents and teachers with the growth of the children, for example, as a function of the increased possibility of observation in more diverse tasks, or linked to the development of the executive functions of the children. Despite the long course of development of these skills, there is evidence of a greater effect of age between approximately five and seven years (Best, Miller, \& Naglieri, 2011), with the children becoming progressively more adept at focusing attention and controlling their behavior between four and five years (Dawson \& Guare, 2010; GarcíaMolina et al., 2009). Thus, the rapid development of these skills in this age group may have been reflected in the performance of the children in the more complex parts of the SST, as well as in the evaluation by the parents and teachers.

One last question refers to whether the scale and test were actually evaluating the same construct. That is, measures of performance, such as the Semantic Stroop Test, provide a standardized and structured condition. Conversely, scales are functional measures, designed to measure the functioning of the child in the day-today in environments much less structured than that of a testing situation. Investigations into this argument need to be performed. At this point, it is worth noting that despite the variation of the correlations established in the different school levels, the score attributed by the parents in the inhibitory control subscale was the only one that was related to some measure of SST in all school levels. This result is consistent, especially when considering the $2^{\text {nd }}$ phase and $1^{\text {st }}$ grade (due to relations with indices of part 2 and interference of the SST), as the performance test used requires inhibition skill for its resolution (Berwid et al., 2005). Thus, the two measures of inhibition, the scale and performance test, were shown to be interrelated with low to moderate magnitude.

There is a tendency to expect relatively consistent results when using different measures, 
such as performance tests and scales, which evaluate the same construct or related constructs. The results found in this study, with low and moderate correlations between the two forms of evaluation, suggest that such measures can be understood as complementary to derive different information, based on ability and functioning in different contexts.

\section{Final Considerations}

Overall, the study showed that there is some concordance, generally low, among informants, parents and teachers, with regard to the evaluation of executive functioning and indicators of inattention and hyperactivity in preschool children and those entering Elementary Education, and that the parents evaluated the children as having more difficulties. There was a greater degree of concordance between the respondents in specific measures, such as inhibitory control and indicators of inattention and hyperactivity, however, only regarding the younger children. Few consistent correlations were observed between the scores in the scales and measures in a performance test. Among these, the relation between the evaluation of inhibitory control by parents and performance of the children in the SST stands out. The relations, however, were not high, indicating a convergence between the measures, although also suggesting that both measure specific aspects.

Study limitations include lack of control for gender and for the specific respondent of the scales sent to be completed by the parents, that is, the mother or father, as well as monitoring of the reading and comprehension of the items by the respondents. The use of a single performance test and the evaluation of a single specific component of the executive functions should also be mentioned. It is suggested that future studies investigate the degree of concordance between the father and mother in the evaluation of the children, investigate the effect of the parental education on the completion to the scales and use other performance tests, which enable a more comprehensive evaluation of the executive functions or other relevant constructs.
These studies will deepen current comprehension of the relations between performance in tests and functional scales, suggesting instruments with greater ecological validity and clarifying the differences between these evaluations. Regarding the implications of this study for the evaluation of executive functions in preschool children and those entering the Elementary Education, the need to use several sources of information is highlighted. That is, the low convergence between the sources, parents and teachers, scales and performance tests, reinforces the need for all of them to be considered together in the childhood evaluation process.

\section{References}

Baddeley, A. (2000). The episodic buffer: A new component of working memory? Trends in Cognitive Sciences, 4(11), 417-423. doi:10.1016/ S1364-6613(00)01538-2

Barkley, R. A. (1997). Behavioral inhibition, sustained attention and executive function: Constructing a unifying theory of ADHD. Psychological Bulletin, 121, 65-94. doi:10.1037/0033-2909.121.1.65

Berwid, O., Kera, E. C., Santra, A., Bender, H., \& Halperin, J. (2005). Sustained attention and response inhibition in preschool children at-risk for AD/HD. Journal of Child Psychology \& Psychiatry, 46(11), 1219-1229. doi:10.1111/ j.1469-7610.2005.00417.x

Best, J. R., Miller, P., \& Naglieri, J. A. (2011). Relations between executive function and academic achievement from ages 5 to 17 in a large, representative national sample. Learning and Individual Differences, 21(4), 327-336. doi:10.1016/j. lindif.2011.01.007

Blair, C., \& Diamond, A. (2008). Biological processes in prevention and intervention: The promotion of self-regulation as a means of preventing school failure. Development and Psychopathology, 20, 899-891. doi:10.1017/S0954579408000436

Blair, C., \& Razza, R. P. (2007). Relating effortful control, executive function, and false-belief understanding to emerging math and literacy ability in kindergarten. Child Development, 78, 647663. doi:10.1111/j.1467-8624.2007.01019.x

Capovilla, A. G. S., \& Dias, N. M. (2008). Desenvolvimento de habilidades atencionais em estudan- 
tes da $1^{\mathrm{a}}$ à $4^{\mathrm{a}}$ sério do ensino fundamental e relação com rendimento escolar. Psicopedagogia, 25(78), 198-211.

Coutinho, G., Mattos, P., Schmitz, M., Fortes, D., \& Borges, M. (2009). Concordância entre relato de pais e professores para sintomas de TDAH: Resultados de uma amostra clínica brasileira. Revista de Psiquiatria Clínica, 36(3), 97-100. doi:10.1590/S0101-60832009000300003

Dawson, P., \& Guare, R. (2010). Executive skills in children and adolescents: A practical guide to assessment and intervention. New York: The Guilford Press.

Diamond, A. (2013). Executive functions. Annual Review of Psychology, 64, 135-168. doi:10.1146/ annurev-psych-113011-143750

Dias, N. M., \& Seabra, A. G. (2013). Funções executivas: Desenvolvimento e intervenção. Temas sobre Desenvolvimento, 19(107), 206-212.

Fonseca, R. P., Oliveira, C. R., Gindri, G., Zimmermann, N., Reppold, C. T., \& Parente, M. A. M. P. (2010). Teste Hayling: Um instrumento de avaliação de componentes das funções executivas. In C. Hutz (Ed.), Avanços em Avaliação Psicológica e Neuropsicológica de crianças e adolescentes (pp. 337-364). São Paulo, SP: Casa do Psicólogo.

García-Molina, A., Enseñat-Cantallops, A., Tirapu-Ustárroz, J., \& Roig-Rovira, T. (2009). Maduración de la corteza prefrontal y desarrollo de las funciones ejecutivas durante los primeros cinco años de vida. Revista Neurologia, 48, 435-440.

Gazzaniga, M. S., Ivry, R. B., \& Mangun, G. R. (2006). Neurociência cognitiva. Porto Alegre, RS: Artmed.

Gonçalves, H. A., Mohr, R. M., Moraes, A. L., Siqueira, L. S., Prando, M. L., \& Fonseca, R. P. (2013). Componentes atencionais e de funções executivas em meninos com TDAH: Dados de uma bateria neuropsicológica flexível. Jornal Brasileiro de Psiquiatria, 62, 13-21. doi:10.1590/S0047-20852013000100003

Guilherme, P. R., Mattos, P., Serra-Pinheiro, M. A., \& Regalla, M. A. (2007). Conflitos conjugais e familiares e presença de transtorno de déficit de atenção e hiperatividade (TDAH) na prole: Revisão sistemática. Jornal Brasileiro de Psiquiatria, 56(3), 201-207. doi:10.1590/S004720852007000300008
Homer, C. J., Baltz, R. D., Hickson, G. B., Miles, P. V., Newman, T. B., Shook, J. E., \& Zurhellen, W. M. (2000). Clinical practice guideline: Diagnosis and evaluation of the child with attention-deficit/ hyperactivity disorder. American Academy of Pediatrics, 105(5), 1158-1170.

Lezak, M. D., Howieson, D. B., \& Loring, D. W. (2004). Neuropsychological assessment ( $4^{\text {th }} \mathrm{ed}$.). New York: Oxford University Press.

Major, S., \& Seabra-Santos, M. J. (2013). Uso de inventários comportamentais para a avaliação socioemocional em idade pré-escolar. Avaliação Psicológica, 12(1), 101-107.

Malloy-Diniz, L. F., Sedo, M., Fuentes, D., \& Leite, W. B. (2008). Neuropsicologia das funções executivas. In D. Fuentes, L. F. Malloy-Diniz, C. H. P. Camargo, \& R. M. Cosenza (Eds.), Neuropsicologia teoria e prática (pp. 387-206). Porto Alegre, RS: Artmed.

Mattos, P., Serra-Pinheiro, M. A., Rohde, L. M., \& Pinto, D. (2006). Apresentação de uma versão em português para uso no Brasil do instrumento MTA-SNAP-IV de avaliação de sintomas de transtorno do déficit de atenção/hiperatividade e sintomas de transtorno desafiador e de oposição. Revista de Psiquiatria do Rio Grande do Sul, 28(3), 290-297.

Menezes, A., Godoy, S., Teixeira, M. C. T. V., Carreiro, L. R. R., \& Seabra, A. G. (2012). Definições teóricas acerca das funções executivas e da atenção. In A. G. Seabra \& N. M. Dias (Eds.), Avaliação neuropsicológica cognitiva: Atenção e funções executivas: Vol. 1 (pp. 34-41). São Paulo, SP: Memnon.

Mitsis, E. M., McKay, K. E., Schulz, K. P., Newcorn, J. H., \& Halperin, J. M. (2000). Parentteacher concordance for DSM-IV Attention Deficit/Hyperactive Disorder in a clinic-referred sample. Journal of the American Academy of Child \& Adolescent Psychiatry, 39(3), 308-313. doi:10.1097/00004583-200003000-00012

Miyake, A., Friedman, N. P., Emerson, M. J., Witzki, A. H., \& Howerter, A. (2000). The unity and diversity of executive functions and their contributions to complex "Frontal Lobe" tasks: A latent variable analysis. Cognitive Psychology, 41, 49100. doi:10.1006/cogp.1999.0734

Nigg, J. (2001). Is ADHD a Disinhibitory Disorder? Psychological Bulletin, 127, 571-598. doi:10.1037//0033-2909.127.5.571 
Pereira, A. P. P., León, C., Dias, N. M., \& Seabra, A. G. (2012). Avaliação de crianças pré-escolares: Relação entre testes de funções executivas e indicadores de desatenção e hiperatividade. Revista Psicopedagogia, 29(90), 279-289.

Seabra-Santos, M. J., \& Gaspar, M. F. (2012). Pais, educadores e testes: Estão de acordo na avaliação de aptidões de crianças pré-escolares? Psicologia: Reflexão e Crítica, 25, 203-211.

Serra-Pinheiro, M. A., Mattos, P., \& Regalla, M. A. (2008). Inattention, hyperactivity, and oppositional-defiant symptoms in Brazilian adolescents: Gender prevalence and agreement between teachers and parents in a non-English speaking population. Journal of Attention Disorders, 12(2), 135-140. doi:10.1177/1087054708314620

Thorell, L., \& Nyberg, L. (2008). The Childhood Executive Functioning Inventory (CHEXI): A new rating instrument for parents and teachers. Developmental Neuropsychology, 33, 536-552. doi:10.1080/87565640802101516.

Trevisan, B. T. (2010) Atenção e controle inibitório em pré-escolares e correlação com indicadores de desatenção e hiperatividade (Dissertação de mestrado, Programa de Pós-Graduação em Distúrbios do Desenvolvimento, Universidade Presbiteriana Mackenzie, São Paulo, SP, Brasil).

Trevisan, B. T., Dias, N. M., Prust, A. P., Martoni, A. T., Santana, T., \& Seabra, A. G. (2011). Tradução e adaptação da Childhood Executive Functioning Inventory (CHEXI) para o contexto brasileiro. In Anais do XXI Congresso Brasileiro da ABENEPI e I Congresso Internacional da $A B E N E P I$. São Paulo, SP: Associação Brasileira de Neurologia, Psiquiatria Infantil.
Trevisan, B. T., Dias, N. M., Berberian, A. A., \& Seabra, A. G. (in press). Childhood Executive Functioning Inventory: Adaptation and psychometric features of the Brazilian version. Psico-USF, 22(1).

Vitaro, F., Brendgen, M., Larose, S., \& Tremblay, R. E. (2005). Kindergarten disruptive behaviors, protective factors, and educational achievement by early adulthood. Journal of Educational Psychology, 97(4), 617-629. doi:10.1037/00220663.97.4.617

Willcutt, E. G., Doyle, A. E., Nigg, J. T., Faraone, S. V., \& Pennington, B. F. (2005). Validity of the executive function theory of attentiondeficit/hyperactivity disorder: A meta-analytic review. Biological Psychiatry, 57, 1336-1346. doi:10.1016/j.biopsych.2005.02.006

Zucker, M., Morris, M., Ingram, S. M., Morris, R. D., \& Bakeman, R. (2002). Concordance of self- and informant ratings of adults' current and childhood attention-deficit/hyperactivity disorder symptoms. Psychological Assessment, 14, 379-389.
Recebido: $22 / 04 / 2014$

$1^{a}$ revisão: $11 / 10 / 2014$

$2^{a}$ revisão: $29 / 01 / 2015$ Aceite final: 10/02/2015 